TPeriodica Polytechnica Civil Engineering

OnlineFirst (2018) paper 10715

https://doi.org/10.3311/PPci.10715

Creative Commons Attribution (i)

RESEARCH ARTICLE

\section{Experimental Results on Masonry Infilled RC Frames for Monotonic Increasing and Cyclic Lateral Load}

\author{
István Haris $^{1 *}$, György Farkas ${ }^{1}$
}

Received 08 March 2017; Accepted 31 January 2018

\begin{abstract}
The main goal of this paper is to present an executed research experiment, planned to include a group of 15, one-third scale, one-bay, two-storey reinforced concrete (RC) frame specimens infilled with masonries with different stiffness. The aim of the complete research experiment was to analyse, in accordance with the international scientific research trend, the behaviour of masonry infilled concrete frames for earthquake action, particularly for cyclic lateral loading under and over the appearance of the main continuous diagonal, corner-to-corner cracks. In the first step the infilled frames were loaded in one direction with monotonic increasing lateral loads. In the second step of the research the infilled frames were investigated in two lateral directions in cases of cyclic top loading with different load histories. This paper shows the conclusions of the experimental programme.
\end{abstract}

\section{Keywords}

masonry infilled RC frames, cyclic load, lateral load

\footnotetext{
1 Budapest University of Technology and Economics, Budapest, Hungary

* Corresponding author, email: haris.istvan@epito.bme.hu
}

\section{Introduction}

In many countries it is a common practice to infill some of the bays of the steel and/or concrete frame. Traditionally infill walls are usually considered as non-load-bearing, non-primary structural elements. Only the concrete frame is assumed to carry horizontal and lateral loads. The most common effect in Hungary, which can be a lateral effect during the lifetime of a building according to the valid standard Eurocode 6, is wind load. However, depending on their construction details, infill masonries can adversely influence the seismic behaviour of the whole structure. Special attention has been nowadays given to the examination of lateral cyclic horizontal loading, principally the seismic vulnerability of masonry infilled concrete frames. Recent earthquakes have shown how much this topic is still essential nowadays, both for existing and newly designed constructions [3].

In order to understand the behaviour of masonry infilled concrete frames for cyclic lateral loading, a research experiment was started at BUTE in Hungary. To describe and specify the behaviour of infilled frames under lateral loading, one-third scale, one-bay, two-storey reinforced concrete (RC) frame specimens (15 pieces) were tested at the Structural Laboratory of the Department of Structural Engineering. The first experimental tests ( 9 pieces) involved the examination of the infilled RC frames subject to monotonic increasing lateral loads. As a next step, the specimens (6 pieces) exposed to cyclic lateral loads were tested. The results and conclusions of the specimens tested under monotonic increasing loads were the basis of the experimental studies on cyclic lateral loads. The effective and useable load histories were defined according to those considerations.

The main goal of the experimental programme was to specify the behaviour of infilled RC frames for cyclic lateral loads, especially when the main continuous diagonal corner-to-corner crack evolved in the infill masonry, called the "yield point" of the masonry [1] [5] [6].

Many analytical and experimental results showed that due to changes in stiffness and mass, the dynamic characteristic/ response of the whole structure also changed [4] [10]. The infill masonry has an effect on both global and local failure modes, 
new and unexpected (by the unfilled frames) and un-designed forms of failure could appear [12].

The first international scientific studies were published by [8] [9]. The structural behaviour of an infilled frame for lateral load was classified into three main stages, see Figure 1.

a) $1^{\text {st }}$ stage
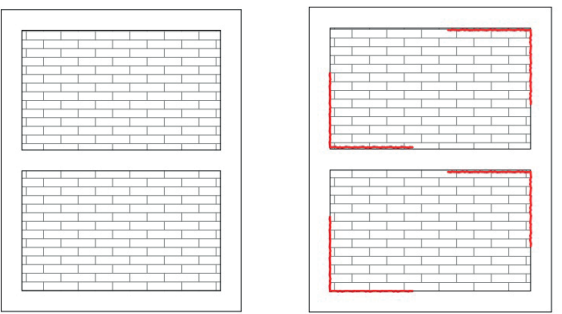

Fig. 1 Behaviour of infilled frames according to Polyakov [8]

At the $1^{\text {st }}$, inchoative stage (Figure 1/a) the infill masonry and the RC frame are not separated under the relatively low lateral force, and work as a "quasi-monolithic" system. At the end of the 1 st stage, the so-called "contour cracks" appear. In the $2^{\text {nd }}$ stage the masonry and the frame are separated into two parts along the increasing contour cracks, but still stay in connection (Figure $1 / \mathrm{b}$ ). At the same time diagonal cracks evolve in the masonry around the compressed sections. The $3^{\text {rd }}$ stage is the ultimate load carrying capacity (Figure 1/c) according to Polyakov.

After the investigations by [8] the infill masonry was replaced by an equivalent compressed diagonal strut. Smith and Carter [13] defined the equivalent cross-sectional area of the strut in a closed formula. Finally, Saneinejad and Hobbs [11] published an article including the main results, which are taken as a pillar of this theme by today's researchers. Shing and Mehrabi [12] defined the five most common failure modes and the effective ultimate load carrying capacity of weakly and strongly masonry-infilled frames.

By the evolution of the softwares used in the structural design process many analytical and numerical models and results [5] [7] were published. Above all, many experimental results were also presented in connection with masonry infilled steel frames [14] and concrete frames [1] [2] [3].

\section{Experimental study}

\subsection{Tested specimens}

In the experimental part of the study, one-third scale, onebay, two-storey reinforced concrete (RC) frames were used as specimens in the execution of the tests. On the whole, 15 specimens were tested; the dimensions and the reinforcements of the concrete skeleton are shown in Figure 2. The ratio of one-storey infill height $(\mathrm{h})$ to length $(\ell), \mathrm{h} / \ell$ is 0.595 .

The concrete skeletons were prefabricated in a concrete factory. Test frames were intentionally designed to include the most common deficiencies observed in practice, such as restrained connections between beams and columns. The bending stiffness of the columns was much smaller than the bending stiffness of the beams, even if common characteristics of materials (reinforcement and concrete) were used, see Table 1.

\begin{tabular}{lcc}
\multicolumn{2}{c}{ Table 1 Classification of the materials used } \\
\hline Material used & \multicolumn{1}{c}{ Classification } \\
\hline Concrete & $\mathrm{C} 20 / 25$ & $\mathrm{f}_{\mathrm{ck}}=20 \mathrm{~N} / \mathrm{mm}^{2}$ \\
Steel reinforcement & $\mathrm{S} 500 \mathrm{~B}$ & $\mathrm{f}_{\mathrm{yk}}=500 \mathrm{~N} / \mathrm{mm}^{2}$ \\
\hline
\end{tabular}

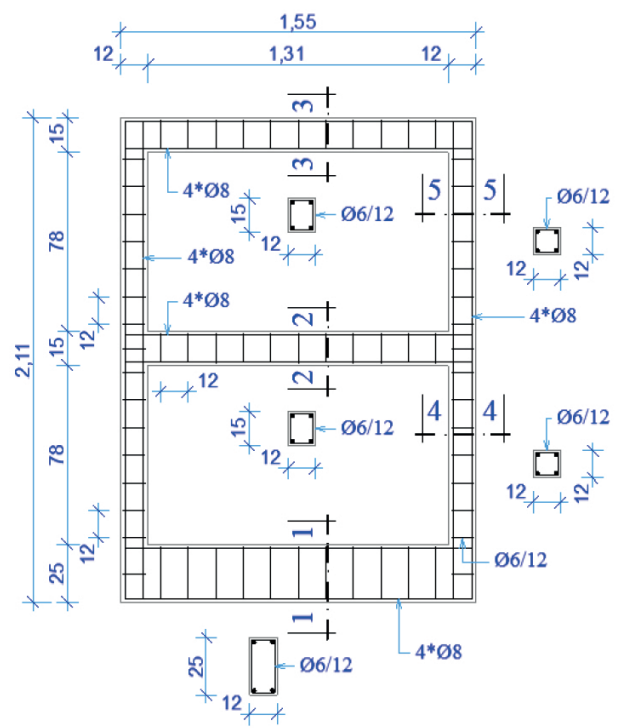

Fig. 2 Dimensions and reinforcements of the test frames

\subsection{Infill masonry}

The RC frame was posteriorly infilled by masonry at the laboratory. The masonry unit used was the so-called "classic" solid small brick with dimensions of $6.5 * 12 * 25 \mathrm{~cm}$, and each of the elements were cut into three uniform pieces to take into consideration the scale of the RC test frame, see Figure 3.

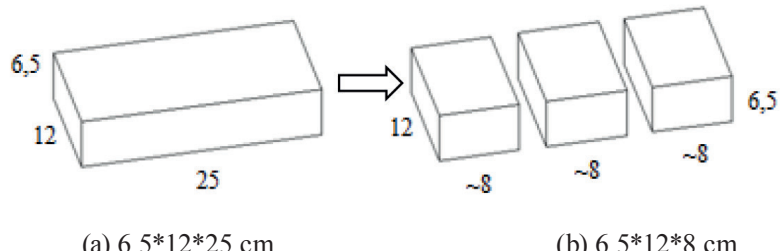

Fig. 3 The "classic" solid small brick in Hungary

The mean compressive strength of the masonry unit (data given by the factory) is $\mathrm{f}_{\mathrm{k}}=10 \mathrm{~N} / \mathrm{mm}^{2}$. The normalized compressive strength of the units cut $(6.5 * 12 * 8 \mathrm{~cm})$ calculated according to EC6 was $\mathrm{f}_{\mathrm{b}}=8.57 \mathrm{kN} / \mathrm{mm}^{2}$. The average thickness of both mortar layers was about 3-3.5 mm, and the whole surface was covered with mortar. The RC frames were infilled from the top to the bottom, namely first the upper storey was infilled, to be followed by the lower one.

\subsection{Mortar}

According to the national scientific literature using case studies it can be established that in case of so-called "normal" masonries essentially different structural failures can evolve 
in the ratio of the compressive strength of the mortar and the masonry unit. If the compressive strength of the masonry unit is twice higher than the compressive strength of the mortar, the main failure of the mortar is expected to occur under lateral loading. On the contrary, if the compressive strength of the mortar is the higher one, the traverse main cracks will come across the masonry units too. To take these into consideration two different mortars were used in the experiments, see Table 2.

Table 2 Classification of the mortars designed

\begin{tabular}{lc}
\hline Classification of mortar & Compr. strength $\mathrm{f}_{\mathrm{m}}\left[\mathrm{N} / \mathrm{mm}^{2}\right]$ \\
\hline Baumit M30 & 3 \\
\hline Baumit M100 & 10 \\
\hline
\end{tabular}

Both main values of the material characteristics were checked in the laboratory for the concrete, the reinforcement and the masonry unit as well. The differences between the designed and the measured values were similar to each other, except for the compression strength of the mortar, see Table 3.

Table 3 Classification of the executed mortars

\begin{tabular}{cccc}
\hline \multicolumn{2}{c}{ Monotonic loading } & \multicolumn{2}{c}{ Cyclic loading } \\
\hline Sign of specimen & $\begin{array}{c}\text { Executed class. } \\
\mathrm{f}_{\mathrm{m}}\left[\mathrm{N} / \mathrm{mm}^{2}\right]\end{array}$ & Sign of specimen & $\begin{array}{c}\text { Executed class. } \\
\mathrm{f}_{\mathrm{m}}\left[\mathrm{N} / \mathrm{mm}^{2}\right]\end{array}$ \\
\hline Km1-1 & 2.3 & $\mathrm{Kc1}-1$ & 2.4 \\
Km1-2 & 2.7 & $\mathrm{Kc1}-2$ & 4.2 \\
Km1-3 & 3.3 & $\mathrm{Kc1-3}$ & 2.0 \\
$\mathrm{Km} 2-1$ & 9.3 & $\mathrm{Kc2}-1$ & 8.1 \\
$\mathrm{Km} 2-2$ & 8.0 & $\mathrm{Kc2}-2$ & 7.8 \\
$\mathrm{Km} 2-3$ & 8.5 & $\mathrm{Kc2}-3$ & 8.0 \\
\hline
\end{tabular}

The infill masonry was continually chocked to the concrete surface using steel plates, see Figure 4.

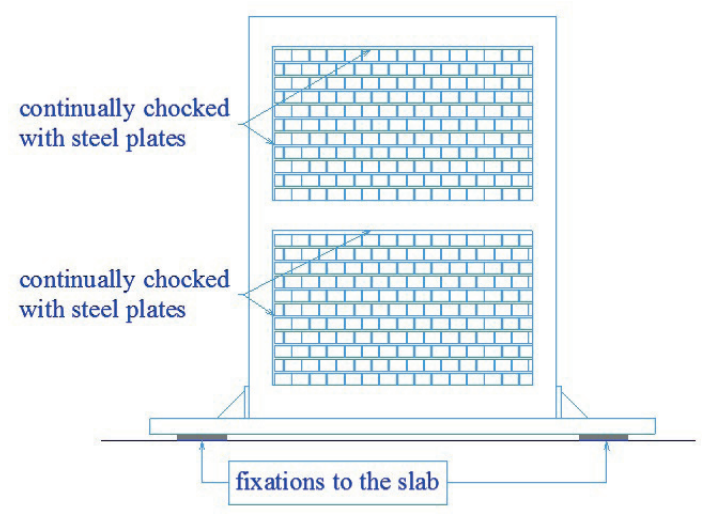

Fig. 4 The infilled frame specimen

\section{Test set-up and procedure}

The test specimens included fifteen RC frames. All the frames had the same internal steel reinforcement and were divided into five series, each consisting of three frames. The first series had no infill masonries, all of the other series were infilled. In the second and fourth series the infill masonries were made of the lower compressive strength mortar (M30), as against the third and fifth series where the higher compressive strength mortar (M100) was used. The second and the fourth series were subjected to monotonic increasing lateral loading, the third and the fifth were in turn exposed to cyclic loading, see Table 4.

Table 4 Experimental programme

\begin{tabular}{lccc}
\hline Sign & Test frame set-up & Pieces & Loading set-up \\
\hline K0 & Not infilled & 3 & monotonic \\
Km1 & Infilled with M30 & 3 & monotonic \\
Km2 & Infilled with M100 & 3 & monotonic \\
Kc1 & Infilled with M30 & 3 & cyclic \\
Kc2 & Infilled with M100 & 3 & cyclic \\
\hline
\end{tabular}

\section{Tests under monotonic increasing lateral load 4.1 Loading and supporting system}

The one-bay, two-storey reinforced concrete (RC) frames were fixed by complementary steel structures to the concrete slab. The static load test consisted of laterally concentrated, monotonic increasing loading $(\mathrm{V})$ at the top beam of the frame besides constant $(100 \mathrm{kN})$ vertical load applied on both columns, see Figure 5. All of the loads were applied by using a hydraulic jack. A very rigid external steel frame was attached to the specimen to prevent any out-of-plane deformations, see also Figure 5.

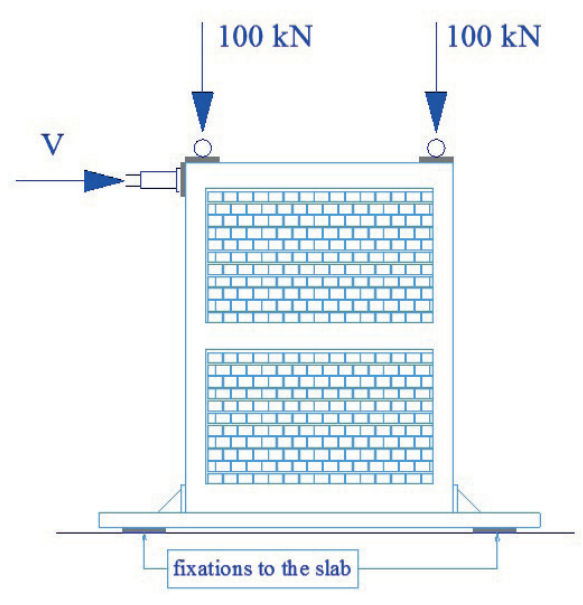

(a) Scheme of the test set-up

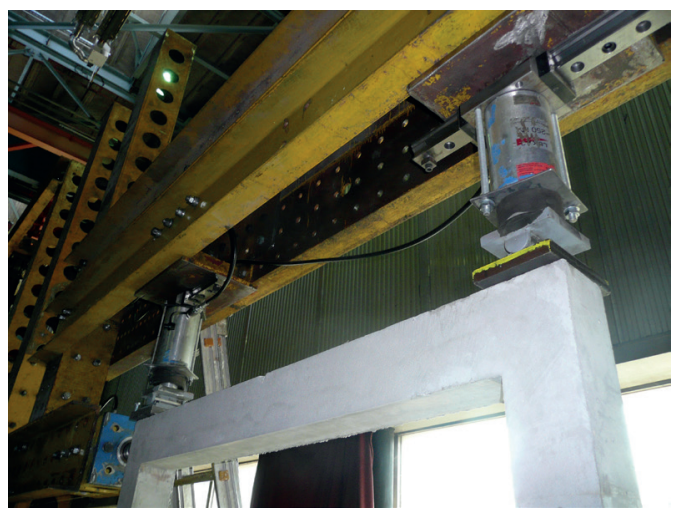

(b) Hydraulic jacks on an unfilled frame

Fig. 5 Loading system 


\subsection{Deformation measurements}

All deformations were measured using inductive displacement transducers, including top drifting under the centre line of the top beam by Type W100 (HBM), relative displacements $(1 \mathrm{e}-8 \mathrm{e})$ between the masonry and the concrete by Type W1 and $\mathrm{W} 1 / 2$, and buckling displacements $(1 \mathrm{k}-5 \mathrm{k})$ normal to the equivalent diagonal strut by Type W1. All the electrical signs were detected and the signals were processed by software and PC (2 pieces of Spyder 8), see Figure 6.

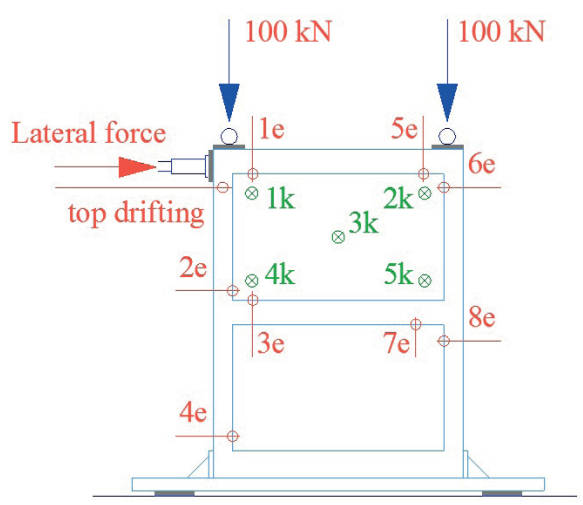

(b) Measurement set-up (front)

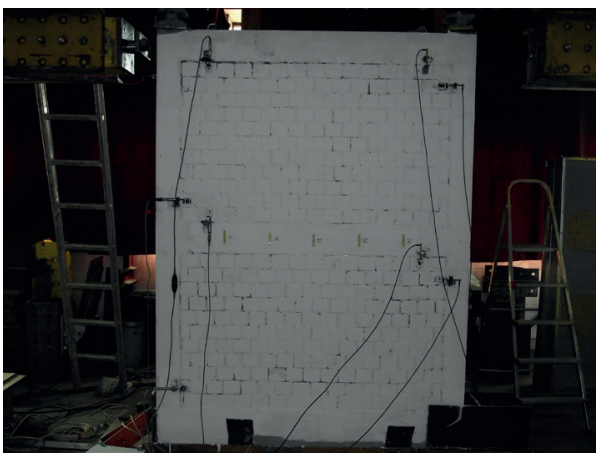

(a) Measurement points on the test frame

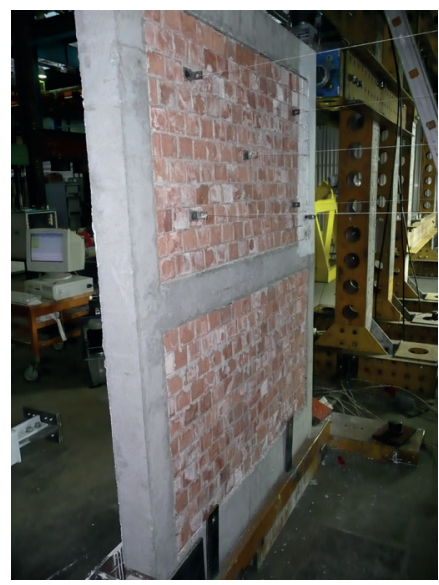

(c) Back-side of the specimen

Fig. 6 Displacement measurement

\subsection{Load histories}

The unfilled skeletons and the first three infilled specimens were loaded by monotonic increasing lateral forces up to collapse, except for Km1-Sp3. In the case of the test group marked $\mathrm{Km} 2$, the load histories contained unload-reload steps at the external lateral forces of $40 \mathrm{kN}, 80 \mathrm{kN}$ and $110 \mathrm{kN}$, respectively.

\subsection{Experimental results}

As a next step, the test frames were evaluated in terms of load versus top displacement. The typical load versus top displacement curves are shown in Figure 7.

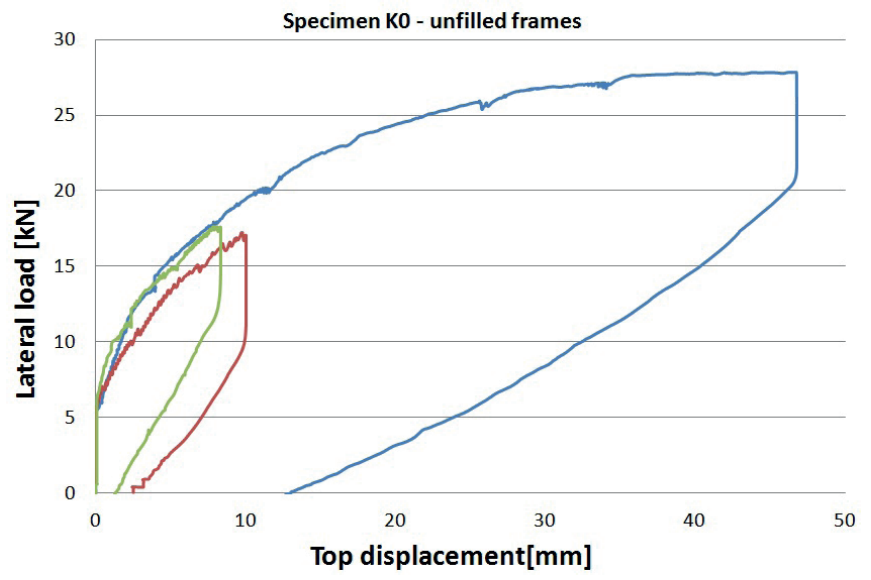

Fig. 7 Load vs. top displacement curves of unfilled test frames (two of the specimens were only loaded up to the first concrete crack, not up to collapse)

The results of the two test series with the different mortars are shown in Figure 8.

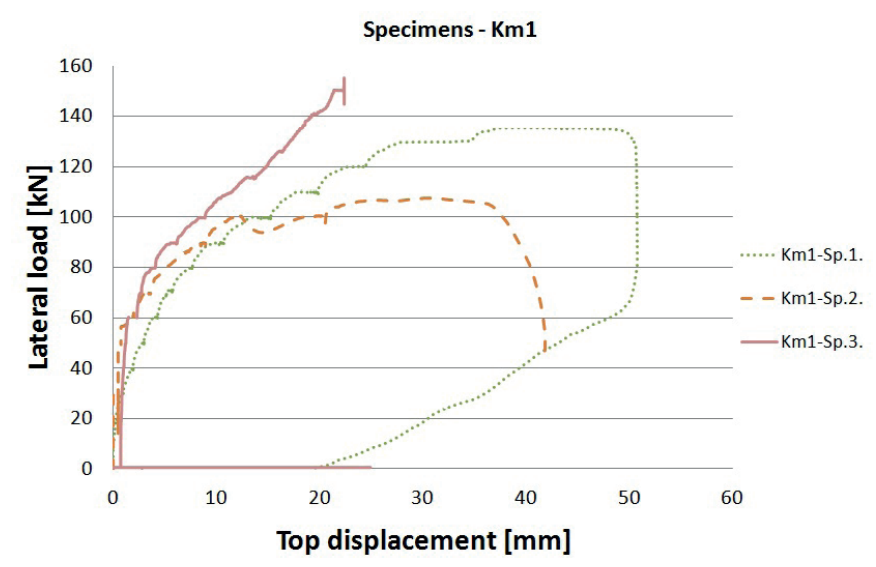

(a) Infilled frames using mortar M30

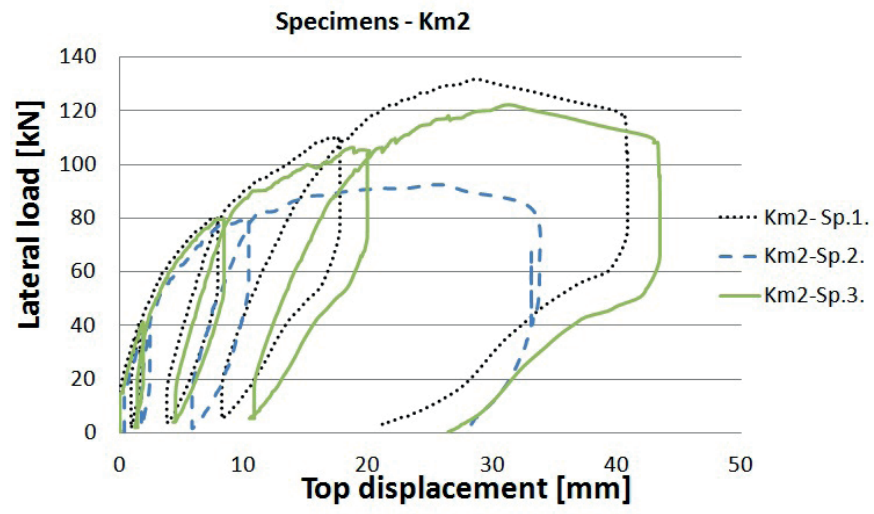

(b) Infilled frames using mortar M100

Fig. 8 Load vs. top displacement curves of the infilled test frames under monotonically increasing loads 


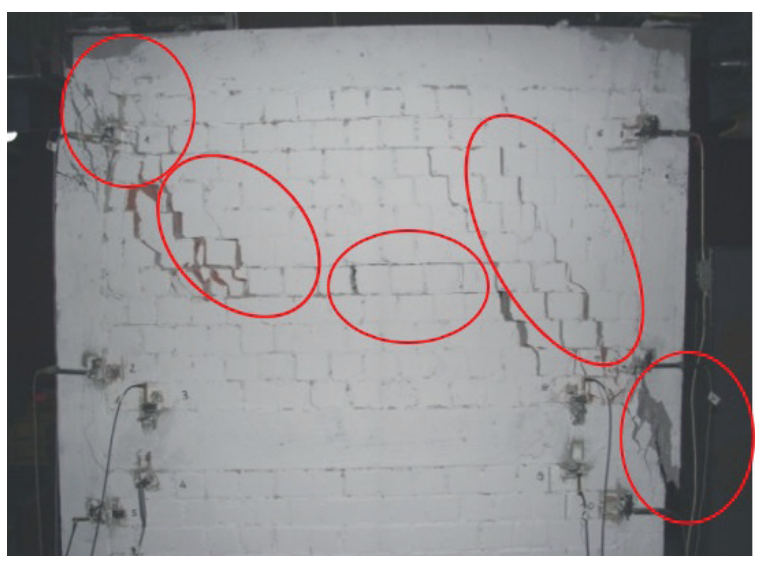

(a) Typical shear cracks on specimen

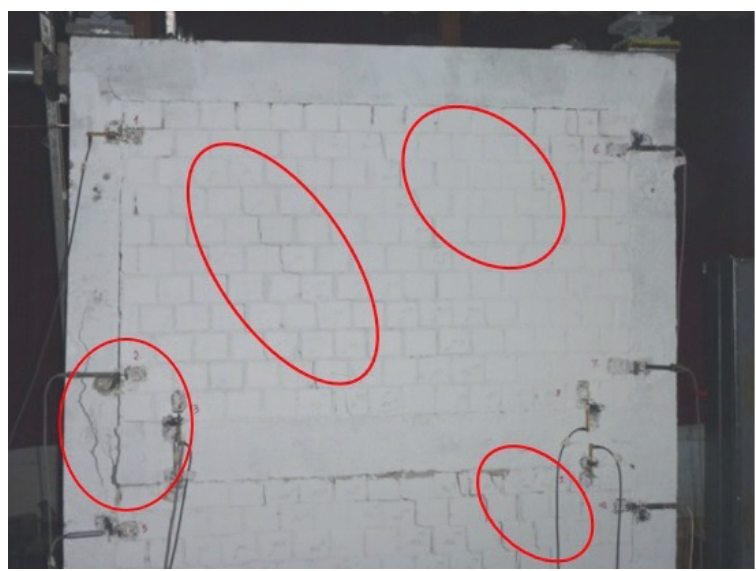

(b) Typical shear cracks on specimen

Fig. 9 Typical failure modes, corner-to-corner cracks of the specimens

In case of specimen Km1-Sp.3, final failure was not tested because this specimen was retained for educational aims at the university. All of the other frames were loaded up to collapse. As the infilled test frame had not been able to carry higher horizontal forces or had been sliding horizontally under constant force, the specimen started to unload. In case of specimens
Km1-Sp.2 and Km2-Sp.2, an execution problem occurred. The steel reinforcements in the right concrete column were in the wrong position at the middle beam-to-column connection, so the shear resistance of the concrete element was significantly decreased. After the first diagonal cracks appeared on the infill and the masonry units were sliced, a very quick shear cracking was observed; that is why the experimental results were lower than the other ones. The point where the main continuous diagonal corner-to-corner crack evolves is hereinafter called as the "yield point" of the infill masonry [6] [1], see Figure 9.

To able to make a comparison between the results of different numerical models and further experimental programmes, the top displacements of the infilled frames at the main measured external lateral load points (yield force of the masonry infill and peak load of the infilled frame) are presented in Table 5.

Table 5 Measured top displacements at infilled frames

\begin{tabular}{lcc}
\hline Sign of spec. & \multicolumn{2}{c}{ Measured top displacement $[\mathrm{mm}]$} \\
& $\mathrm{V}=82 \mathrm{kN}$ & $\mathrm{V}=$ peak load \\
\hline Km1-Sp.1. & 7.65 & 37.4 \\
Km1-Sp.2. & 5.92 & 30.3 \\
Km1-Sp.3. & 4.10 & - \\
\hline $\mathrm{Km} 2-$ Sp.1. & $\mathrm{V}=92 \mathrm{kN}$ & $\mathrm{V}=$ peak load \\
$\mathrm{Km} 2-\mathrm{Sp} .2$. & 10.61 & 28.76 \\
$\mathrm{Km} 2-\mathrm{Sp} .3$. & - & 25.04 \\
\hline $\mathrm{Km}$ & 12.37 & 31.82 \\
\hline
\end{tabular}

(Km1-Sp.3 was not tested up to collapse as it was mentioned before; the value of the peak load of Km2-Sp.2 was lower than $\mathrm{V}=92 \mathrm{kN}$ because of an execution problem)

The following show some of the measured separations between the masonry and the concrete skeleton. Without striving for completeness, typical external load vs. separation curves are shown in Figure 10.

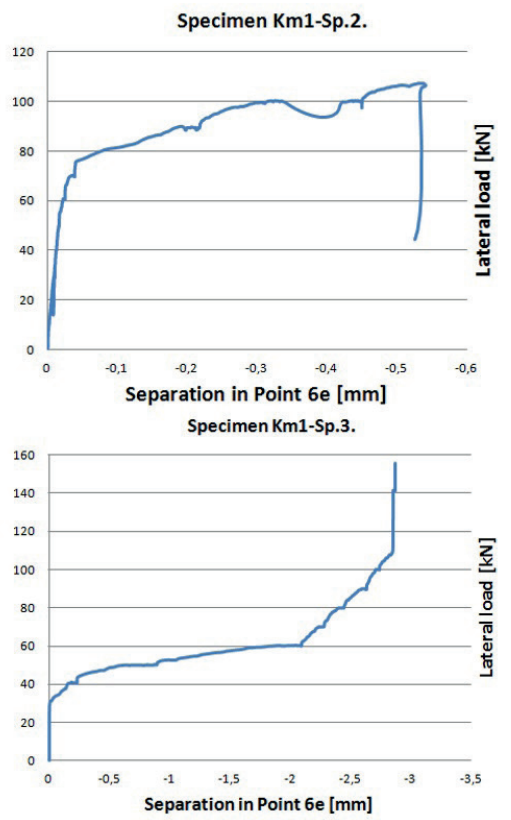

Fig. 10 Typical separation vs. load diagrams 


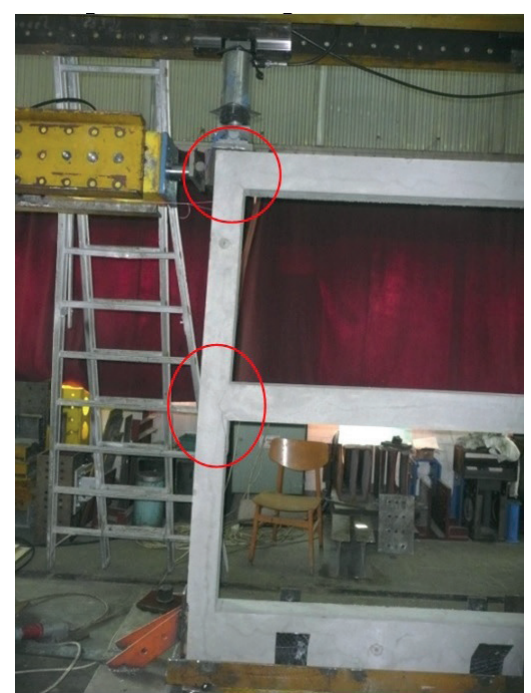

(a) Specimen K0 - Sp.1

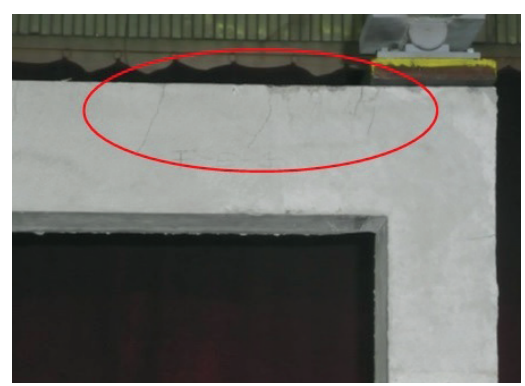

(c) Specimen K0 - Sp.1. and Sp.3.

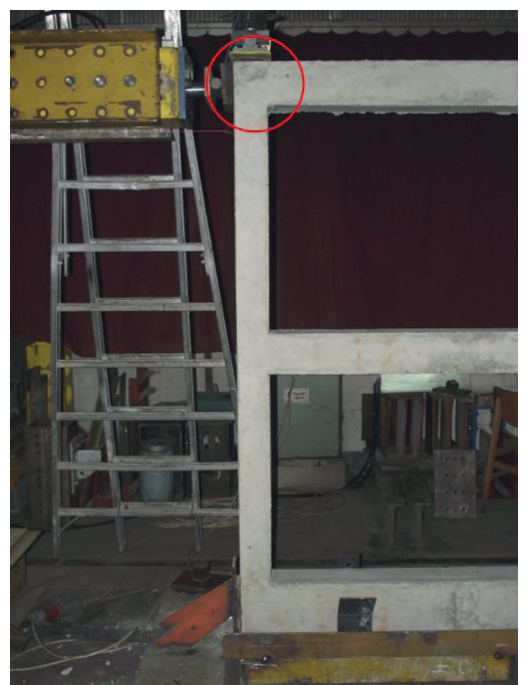

(b) Specimen K0 - Sp.2.

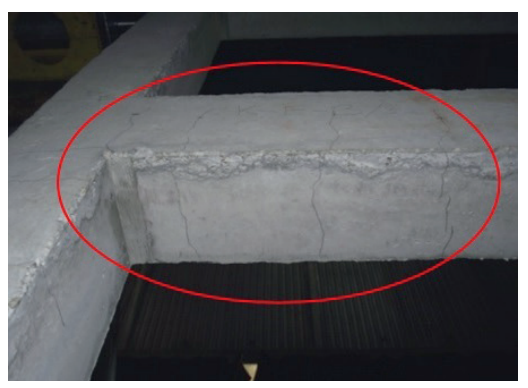

(d) Specimen K0 - Sp.1. and Sp.2.

Fig. 11 Bended cracks of non-filled test frames under lateral load

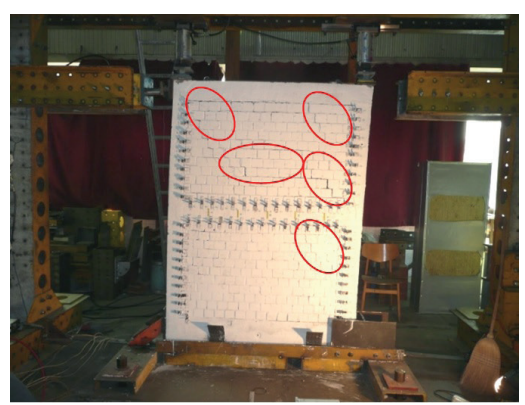

(a) Specimen Km1 - Sp.1. - shear cracks on the infill wall

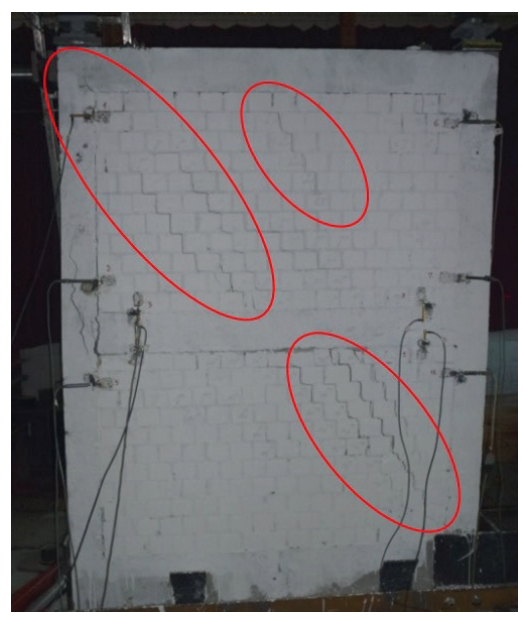

(d) Specimen Km2 - Sp.1. - corner-to-corner cracks

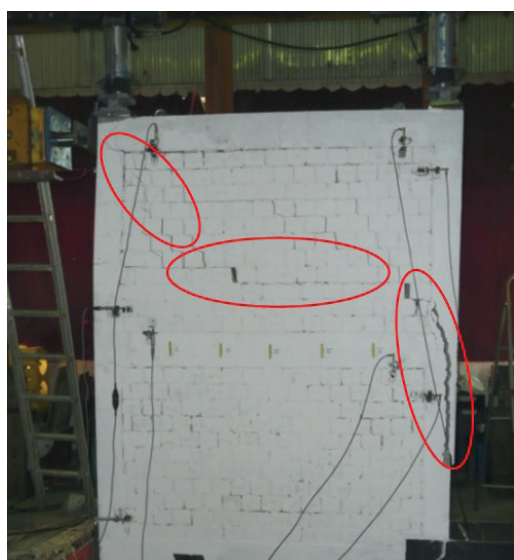

(b) Specimen Km1 - Sp.2. - shear failure of $\mathrm{RC}$ frame corner-to-corner shear cracks on the infill wall

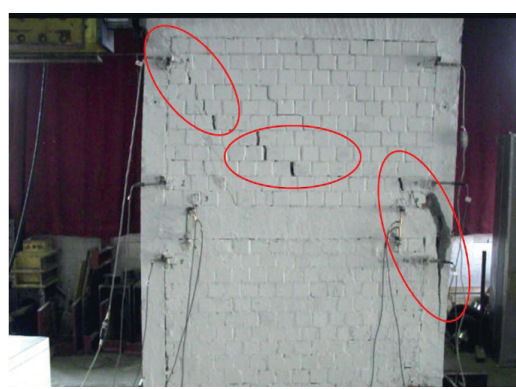

(e) Specimen Km2 - Sp.2. - failure of RC frame

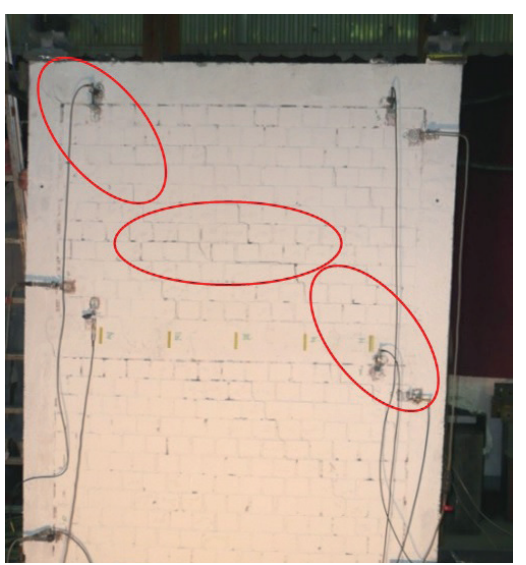

(c) Specimen Km1 - Sp.3. - corner-to-corner cracks

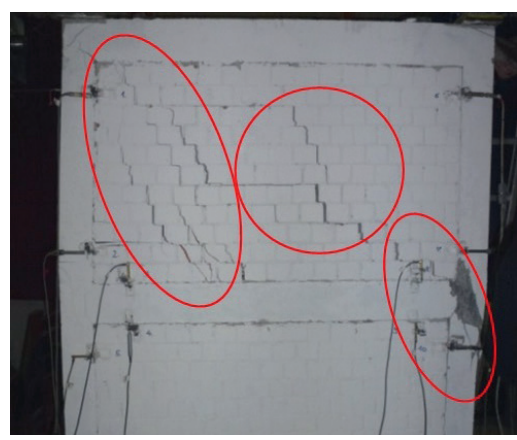

(f) Specimen Km2 - Sp.3. failure of RC frame, corner-to-corner shear cracks sliding in the middle of the wall

Fig. 12 Failures of infilled test frames under monotonic increasing lateral load 
As shown in Figure 10, separation between the infill masonry and the concrete skeleton starts to appear practically at the beginning of lateral loading, though the contour cracks are probably not visible at a quick glance. The $1^{\text {st }}$ behaviour stage (see Figure 1/a above) according to Polyakov does not exist in such form because separation immediately begins. In this case a masonry infilled concrete frame cannot be calculated as a "monolithic" structure.

The failures, the lateral displacements and some of the typical crack patterns of the non-filled reference specimens are presented below in Figure 11.

The failures of the infilled specimens under monotonic increasing lateral load are presented below in Figure 12.

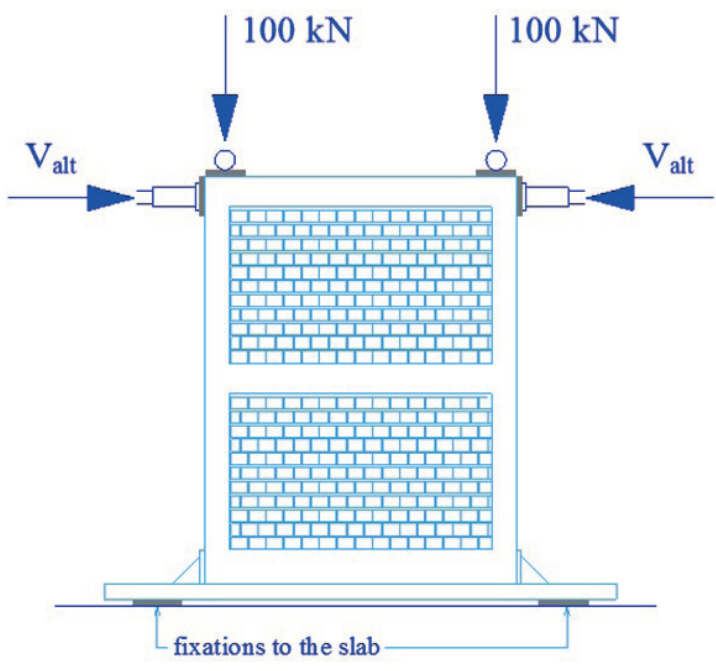

(a) Scheme of the test set-up
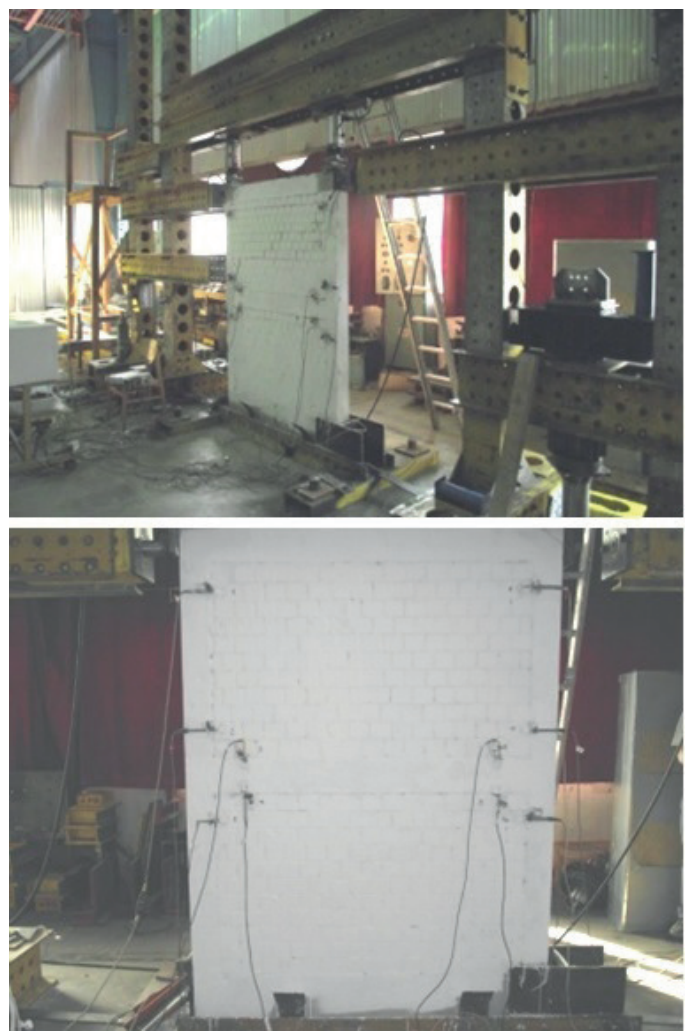

(b) The whole measurement system

Fig. 13 Loading system under cyclic loading

\section{Tests under cyclic lateral load}

\subsection{Loading and supporting system}

The loading and the supporting system of the one-bay, two-storey RC frames were basically the same under cyclic loading as well. The only difference was the second lateral hydraulic jack in the opposite direction, to be able to create quasi-static cyclic load histories, see Figure 13.

\subsection{Deformation measurements}

All deformations were measured by inductive displacement transducers, as introduced previously. The main differences were that the relative displacements (1e-10e) between the masonry and the skeleton were measured at 10 positions ( 2 more positions and symmetric locations) and the buckling displacements were not measured, see Figure 14.

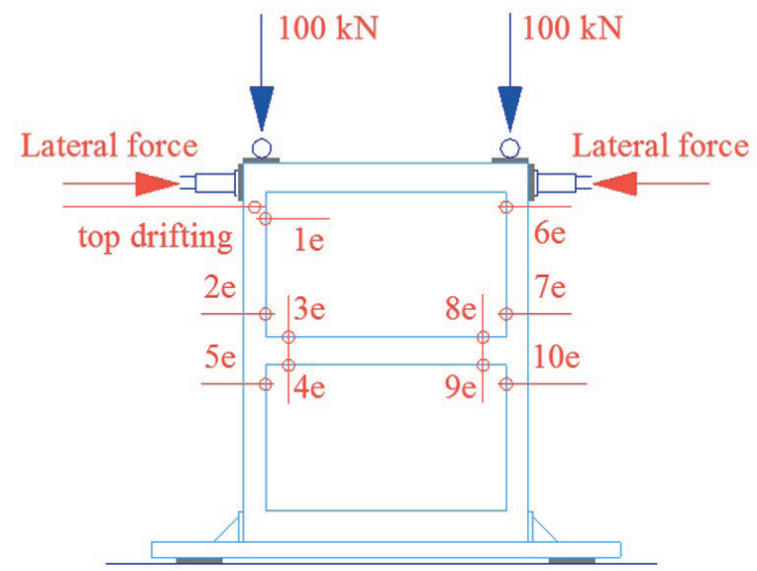

(a) Scheme of measurement points on the test frame

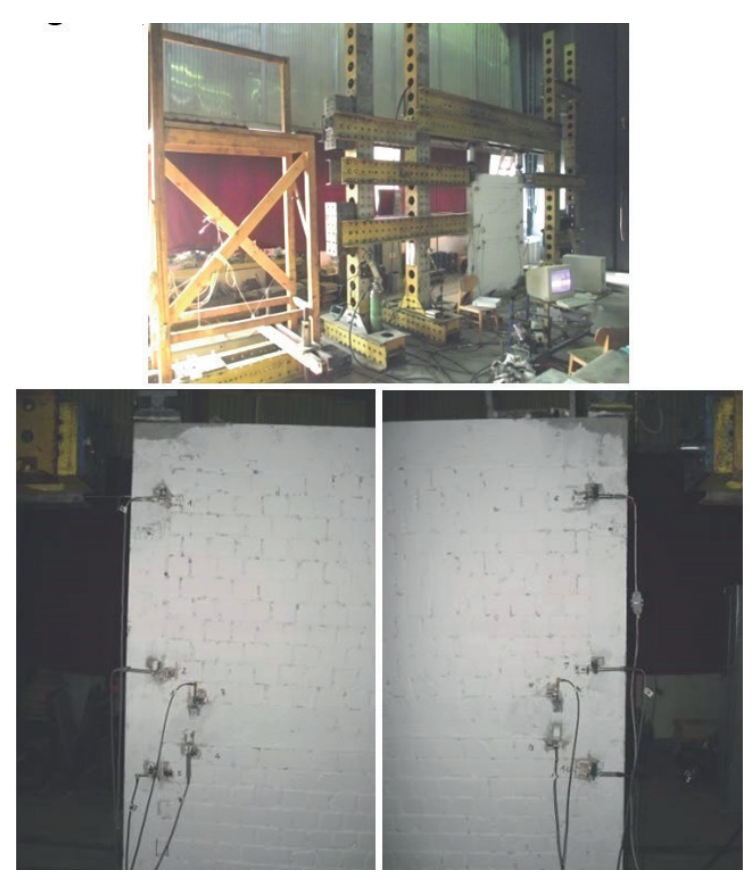

(b) The whole measurement system

Fig. 14 Displacement measurements under cyclic loading 


\subsection{Cyclic load histories}

To be able to examine the behaviour of the infilled $\mathrm{RC}$ frames around the yield force of the infill masonry, all of the cyclic load histories were based on the results of the monotonic increasing load tests and the results of different numerical FE models published by Haris and Hortobágyi [6].

As it was earlier introduced in Table 3, the compressive strengths of the executed mortars were different from the data designed, so the pre-calculated external lateral forces at the yield point of the infill masonry must be revised according to the real material data. So the modified external forces are shown in Table 6.

Table 6 Modified external lateral forces at the yield point of the infill

\begin{tabular}{lc}
\hline Sign & Modified external lateral forces $[\mathrm{kN}]$ \\
\hline Kc1-1 & 75 \\
Kc1-2 & 85 \\
Kc1-3 & 73 \\
Kc2-1 & 95 \\
Kc2-2 & 92 \\
Kc2-3 & 92 \\
\hline
\end{tabular}

The load histories used are shown in Figure 15.
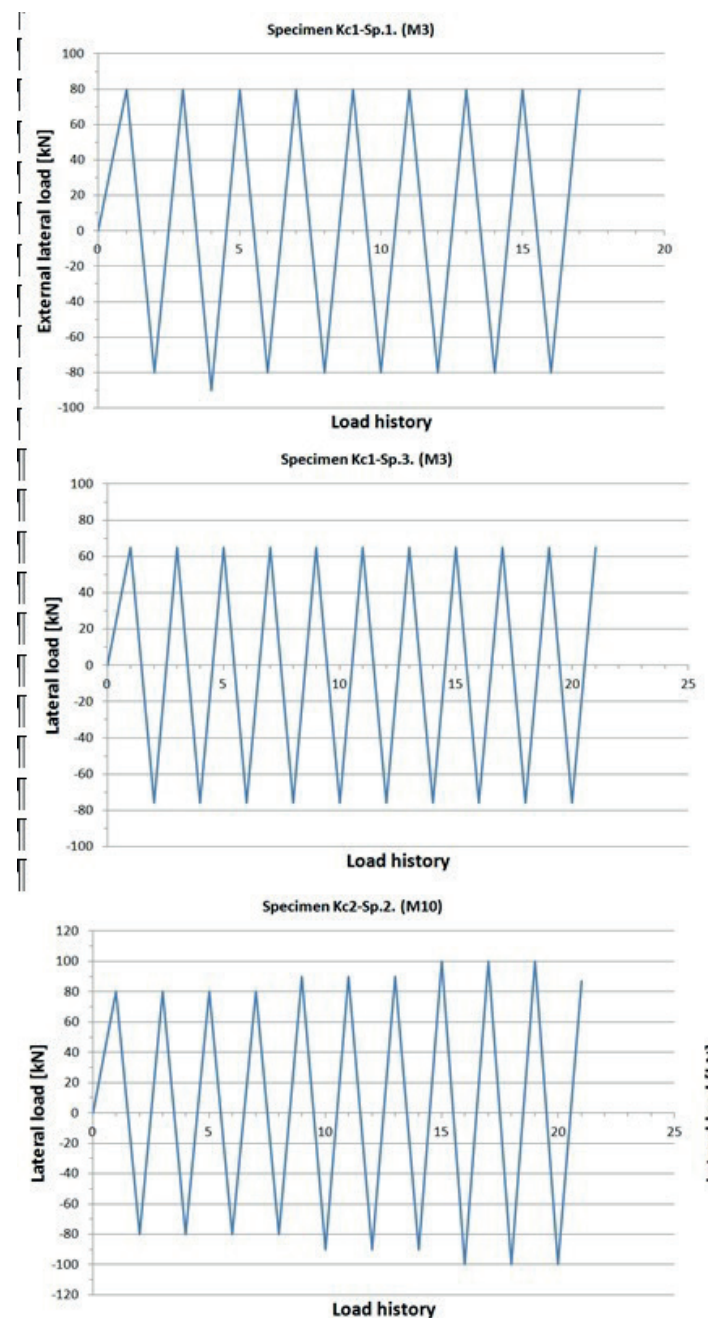

\subsection{Experimental results under cyclic load}

In the following, the test frames are also evaluated in terms of load versus top displacement. The different load vs. top displacement curves are displayed in Figure 16.

All of the external lateral forces at the yield point of the masonry infill, corresponding to the appearance of the main continuous diagonal crack, were measured and determined during the tests, see Table 7 .

Table 7 Measured external lateral load at yield point under cyclic load

\begin{tabular}{lc}
\hline Sign & Measured external lateral load at yield point $[\mathrm{kN}]$ \\
\hline Kc1-1 & $\sim 75$ \\
Kc1-2 & $\sim 92$ \\
Kc1-3 & $\sim 70$ \\
Kc2-1 & $\sim 95$ \\
Kc2-2 & $\sim 90$ \\
Kc2-3 & $\sim 90$ \\
\hline
\end{tabular}

The pre-calculated and the measured external lateral loads highly correspond to each other. At the same time, of course, it should be noticed that the determination of the appearance of the main continuous diagonal crack is not an exact and technically acceptable result, but surely it is a serviceable detection.
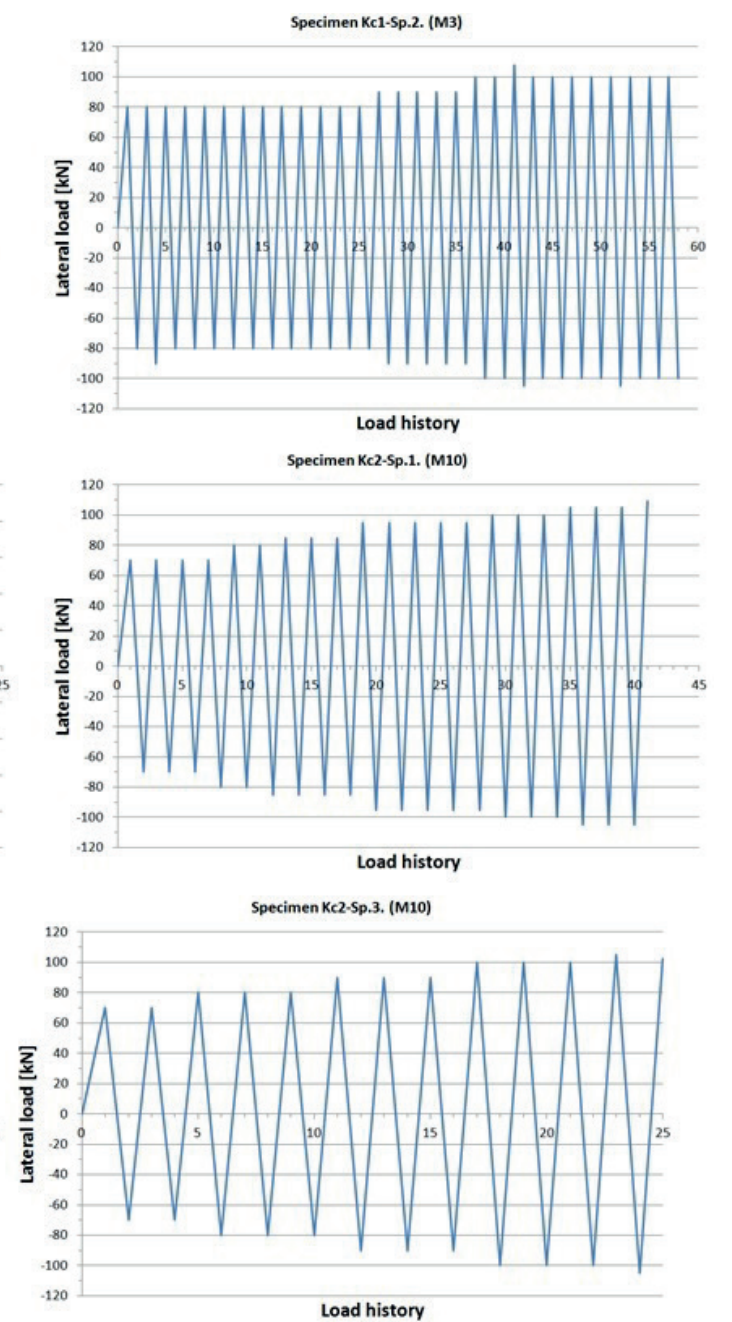

Fig. 15 Cyclic load histories 

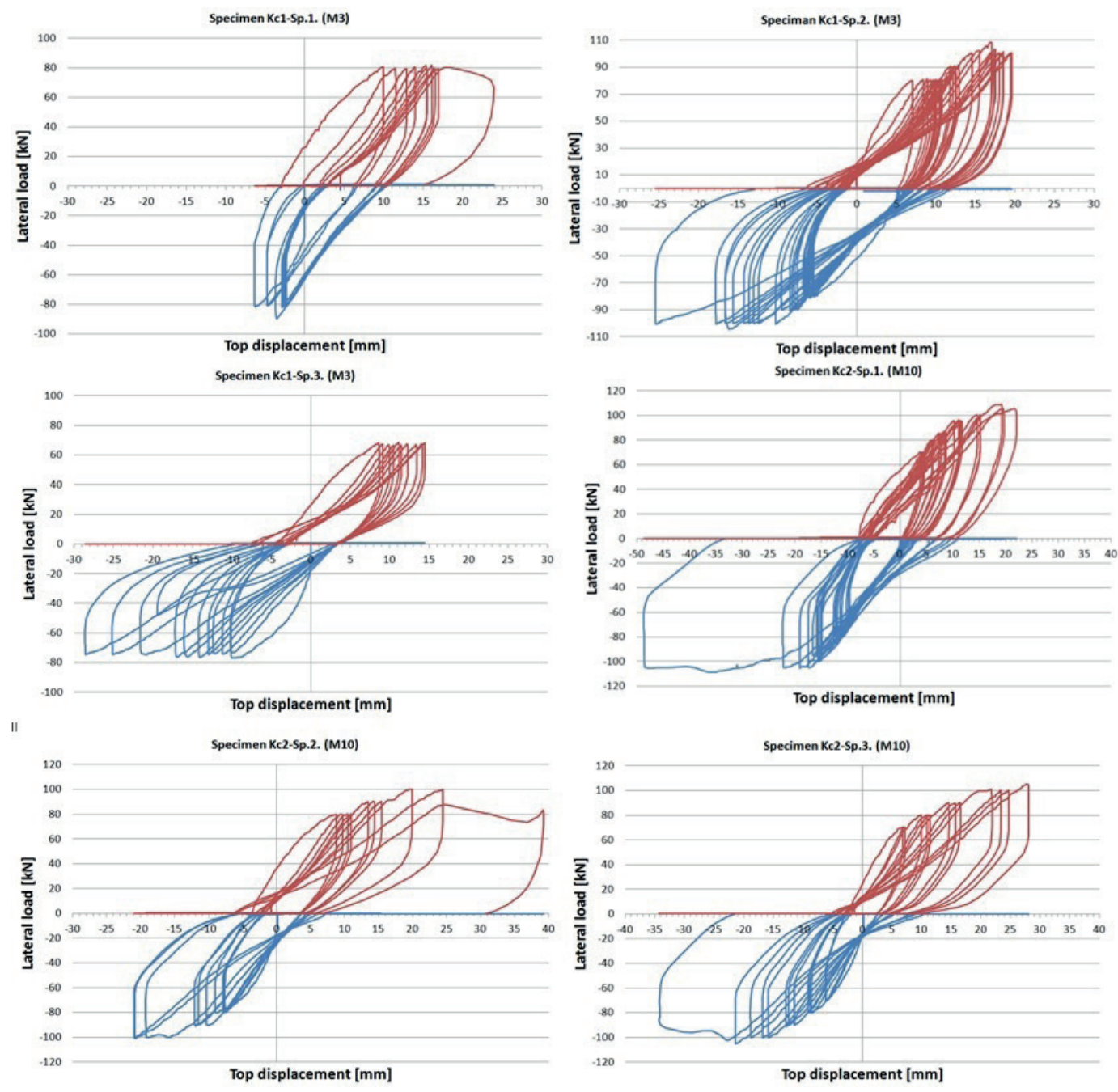

Fig. 16 Load vs. top displacement curves of the infilled test frames under cyclic load

The behaviour of the infill masonry before the appearance of the continuous diagonal corner-to-corner crack significantly diverges from its behaviour following the yield point. Under cyclic forces lower than the yield force, the accumulated residual strains and displacements are smaller in each cycle than in the behaviour of the stage after the yield point. In case of the specimen marked Kc1-Sp.1, the residual top displacements in each cycle under the force $(80 \mathrm{kN})$ - a little bit higher than the calculated and physically determined external lateral force $(75$ $\mathrm{kN})$ - at the yield point of the masonry are about $1.5 \mathrm{~mm}$. Analysing the test results of Kc1-Sp.2, the cyclic residual top displacements are about $0.4 \mathrm{~mm}$ under a force of $80 \mathrm{kN}$, and $\sim 0.5$ $\mathrm{mm}$ under $90 \mathrm{kN}$, and after the yield point $\sim 1.1 \mathrm{~mm}$ residual displacements are measured under $100 \mathrm{kN}$. The differences can be well noted in Figure 7. In case of Kc1-Sp.3, the lateral forces in the first load direction are higher $(76 \mathrm{kN})$, and in the other direction are lower $(65 \mathrm{kN})$ than the yield force $(\sim 70 \mathrm{kN})$. Under the lower force the cyclic residual top displacements are $\sim 0.3$ $\mathrm{mm}$, while under the higher ones they are already $\sim 1.4 \mathrm{~mm}$. In case of the specimen marked Kc2-Sp.1, made of the "stronger" mortar, the measured cyclic residual top displacements are the following at the force level lower than the yield point $(95 \mathrm{kN})$ : $70 \mathrm{kN}-\sim 0.3 \mathrm{~mm}, 80 \mathrm{kN}-\sim 0.35 \mathrm{~mm}, 85 \mathrm{kN}-\sim 0.40 \mathrm{~mm}$. Over the yield force the results are $95 \mathrm{kN}-\sim 1.3 \mathrm{~mm}, 100 \mathrm{kN}-\sim 1.6$ $\mathrm{mm}$, and $105 \mathrm{kN}-\sim 1.8 \mathrm{~mm}$. The tendency is similar at specimen Kc2-Sp.2. Under the external lateral force $(80 \mathrm{kN})$ lower than the calculated yield force $(90 \mathrm{kN})$, the cyclic residual top displacements are $\sim 0.4 \mathrm{~mm}$, under forces over $90 \mathrm{kN}$ are $\sim 1.2$ $\mathrm{mm}$, and already $\sim 3.5 \mathrm{~mm}$ under $100 \mathrm{kN}$. In case of specimen Kc2-Sp.3, the measured cyclic residual top displacements are $\sim 0.3 \mathrm{~mm}$ under $70 \mathrm{kN}$ and $\sim 0.5 \mathrm{~mm}$ under $80 \mathrm{kN}$. After the yield point $(90 \mathrm{kN})$ the cyclic residual displacements are increased, $90 \mathrm{kN}-\sim 1.1 \mathrm{~mm}, 100 \mathrm{kN}-\sim 1.8 \mathrm{~mm}$.

Before the yield point of the infill masonry, much smaller residual top displacements can be measured under the same lateral load in each cycle, meaning that the total failure of the whole structure occurs "slower", and the degradation is also "slower".

After the appearance of the continuous diagonal corner-to-corner crack the residual lateral displacements at the sequential cycles (under higher lateral loads than the yield force) are about two or three times higher than were previously (under lower lateral loads than the yield force). 
In all cases the total failure of the whole structure was the shear crack of the RC frame. This corresponds to the expectations and the results of FEM pre-calculations [5].

The failures of the infilled specimens under cyclic lateral load are presented below in Figure 17.

\section{Conclusions}

The conclusions made below are based on the limited data of experimental tests on masonry infilled RC frames.

The two-storey, one-bay RC test frames displayed similar behaviour under monotonic increasing loads: especially the initial stiffness of the frames, the yield point of the masonry infills and the peak lateral loads were close to each other. Under cyclic lateral loads the responses of the infilled frames also showed good resemblance.

The main goal of the experimental programme executed was to specify the behaviour of infilled RC frames for cyclic lateral load, especially when the main continuous diagonal, corner-to-corner crack is evolved in the infill masonry, which could be a design limit in practical seismic preparation.
By the investigation of the experimental programme of the masonry infilled RC frames under monotonically increasing and cyclic lateral loads introduced above, the following statements can be made:

- influence of the masonry infills on the maximum external top lateral load at the failure point of the $\mathrm{RC}$ frame is approximately $3.5-5$ times higher than without infills,

- separation between masonry and concrete starts to appear practically at the beginning of the loading, therefore Polyakov's 1st behaviour stage in that original form does not exist, and the infilled frame cannot be calculated as a "monolithic" structure,

- in case of the same geometry and reinforcements, lateral top displacement can be reduced by using mortar of higher compressive strength, but the ultimate external lateral load will not be higher; moreover, in most cases decreasing can be noticed,

- in accordance with other experimental results [1] [2] the "yield point" of the infill masonry is defined by the continuous diagonal corner-to-corner crack, which is not equal

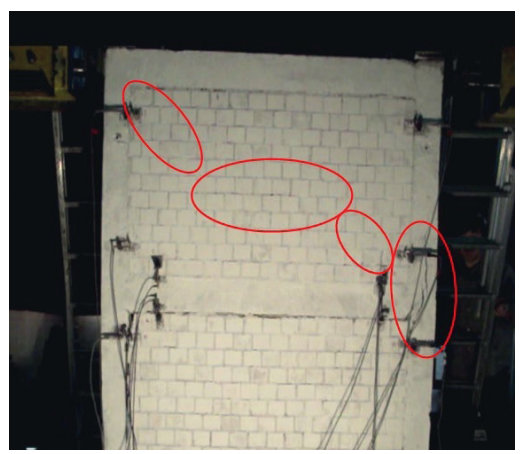

(a) Specimen Kc1 - Sp.1. - shear failure of $\mathrm{RC}$ frame

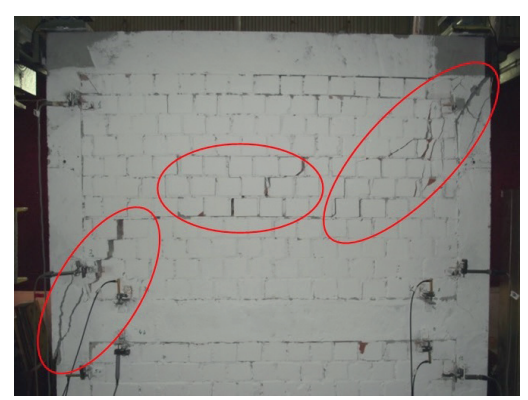

(d) Specimen Kc2 - Sp.1. - shear failure of $\mathrm{RC}$ frame, diagonal cracks on infill wall

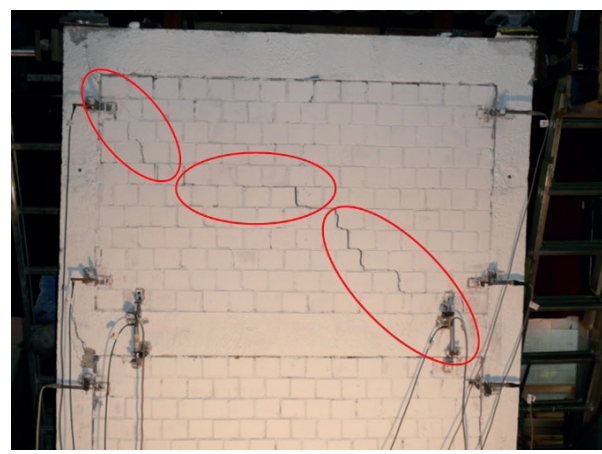

(b) Specimen Kc1 - Sp.2. - corner-to corner cracks on infill

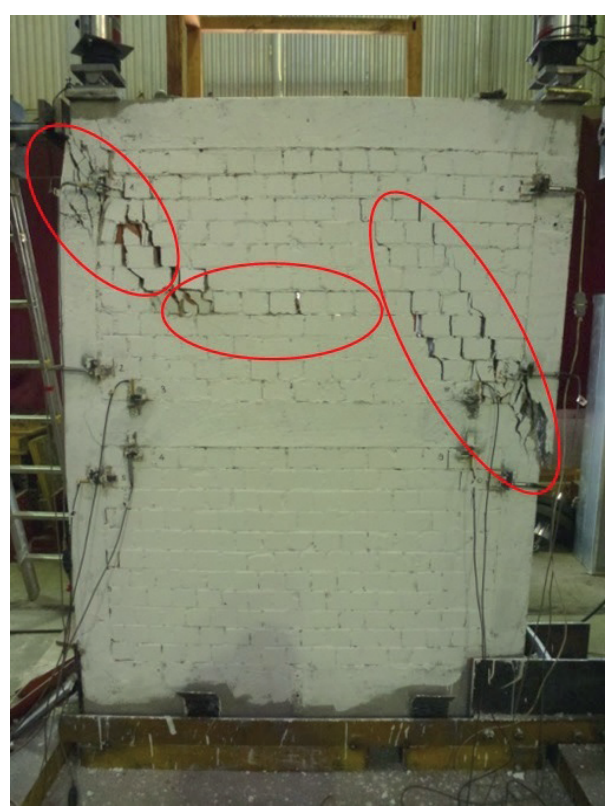

(e) Specimen Kc2 - Sp.2. - shear and bending failure

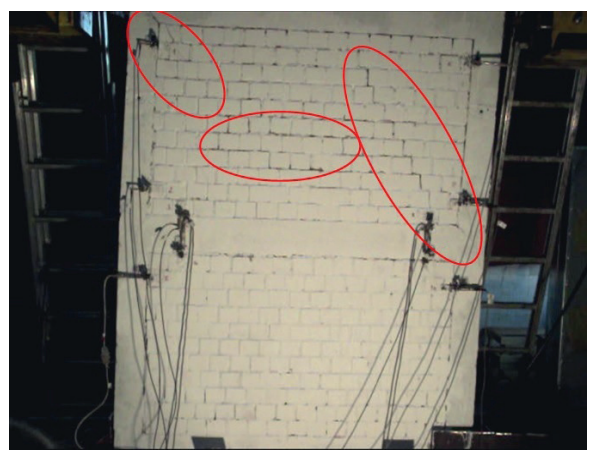

(c) Specimen Kc1 - Sp.3. - diagonal cracks on infill

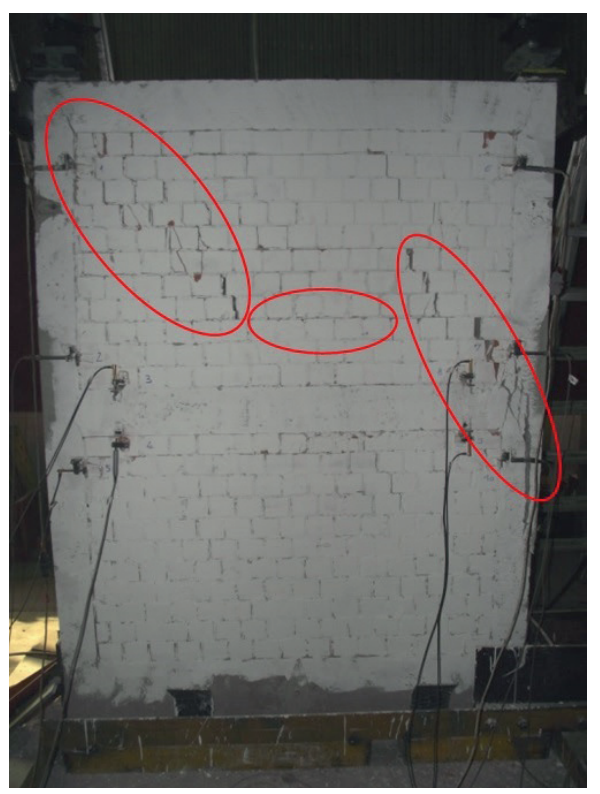

(f) Specimen Kc2 - Sp.3. - shear failure of RC frame, of RC frame, sliding along the diagonal crack diagonal cracks on infill wall

Fig. 17 Failures of the infilled test frames under cyclic lateral load 
to the well-known "first crack" which latter is not corner-to-corner continuous. After the yield point the collapse of the whole structure accelerates along the continuous diagonal corner-to-corner crack,

- Polyakov's $2^{\text {nd }}$ behaviour stage can be easily divided into 2 parts with the appearance of the continuous diagonal corner-to-corner crack,

- for infilled frames with higher stiffness, lower carrying capacity (on the increase) can be noticed after the yield point, and the collapse will be more brittle with smaller plastic deformations,

- the lateral stiffness of the infilled frames can unequivocally increase only up to the yield point of the infill, thereafter a faster collapse can be noticed without significant plastic reserve,

- total lateral top displacements can be reduced by augmenting the stiffness of the infill masonry wall, and probably it can be noticed as a benefit up to the appearance of the continuous diagonal corner-to-corner cracks, but after the yield point the collapse comes to be more and more brittle and the ductility of the frame is wasted,

- after the appearance of the continuous diagonal crack, the residual lateral displacements at the sequential cycles (under higher lateral loads than the yield force) are about two or three times higher than were previously (under lower lateral loads than the yield force),

- much correspondence can be revealed between the calculated and the measured external lateral loads at the yield point of the masonry infill, although the determination of the appearance of the main continuous corner-to-corner diagonal crack is not an exact and technically acceptable result, but surely it is a serviceable detection,

- under the lateral cyclic load, which is lower than the external load attached to the yield point of the masonry, the collapse evolves much more slowly (less cycles are necessary) than when the cyclic load is higher,

- in cyclic design, respect of the reach of the lateral load attached to the appearance of the continuous diagonal corner-to-corner crack is a very important fact because of the quicker evolution of residual lateral displacements at sequential cycles.

\section{References}

[1] Baran, M., Sevil, T. "Analytical and Experimental Studies on Infilled RC Frames". International Journal of the Physical Sciences, 5(13), pp. 1981-1998. 2010. http://www.academicjournals.org/article/article1380817781_Baran\%20and\%20Sevil.pdf

[2] Braz-Cesar, M. T., Oliveira, D., Barros, R. C. "Comparison of Cyclic Response of Reinforced Concrete Infilled Frames with Experimental Results". In: 14th World Conference on Earthquake Engineering, Beijing, China, Oct. 12-17, 2008. https://bibliotecadigital.ipb.pt/bitstream/10198/1796/1/14WCEE\%20-\%2005-03-0204.pdf
[3] Calvi, M. G., Bolognini, D., Penna, A. "Seismic Performance of Masonry-Infilled RC Frames: Benefits of Slight Reinforcements". SÍSMICA 2004- $6^{\circ}$ Congresso National de Sismologia e Engenharia Sísmica, pp. 253-276. 2004. http://www.hms.civil.uminho.pt/events/ sismica2004/253-276_G_Michele_Calvi.pdf

[4] Dulácska, E. "Földrengés elleni védelem, egyszerű tervezés az Eurocode 8 alapján" (in Hungarian) (Earthquake protection, simple design based on Eurocode 8), Practical guide, PI Innovációs Kft., Budapest, 2009.

[5] Haris, I., Hortobágyi, Zs. "Different FEM models of Reinforced Concrete Frames Stiffened by Infill Masonry for Lateral Loads". Periodica Polytechnica Civil Engineering, 56(1), pp. 25-34. 2012. https://doi.org/10.3311/pp.ci.2012-1.03

[6] Haris, I., Hortobágyi, Zs. "Comparison of Experimental and Analytical Results on Masonry Infilled RC Frames for Monotonic Increasing Lateral Load". Periodica Polytechnica Civil Engineering, 59(2), pp. 193-208. 2015.

https://doi.org/10.3311/PPci.8099

[7] Lourenço, P. B., Alvaregna, R. C., Silva, R. M. "Validation of a Simplified Model for the Design of Masonry Infilled Frames". Masonry International, 19(1), pp. 15-26. 2006. https://www.masonry.org.uk/ downloads/validation-of-a-simplified-model-for-the-design-of-masonry-infilled-frames/

[8] Polyakov, S. V. "Masonry in Framed Buildings: Investigations into the Strength and Stiffness of Masonry Infilling", Boston Spa, Yorkshire: National Lending Library for Science and Technology, 1963.

[9] Polyakov, S. V. "On the interaction between masonry filler walls and enclosing frame when loaded in the plane of the wall", Earthquake Engineering, Earthquake Engineering Research Institute, San Francisco, pp. 36-42. 1960.

[10] Puyol, S., Benavent-Client, A., Rodriguez, M. E., Smith-Pardo, J. P. "Masonry Infill Walls: An Effective Alternative for Seismic Strengthening of Low-rise Reinforced Concrete Building Structures". In: 14th World Conference on Earthquake Engineering, Beijing, China, Oct. 12-17, 2008. http://www.abam.com/sites/default/files/tech-papers/ tp-MasonryInfillWalls.pdf

[11] Saneinejad, A., Hobbs, B. "Inelastic Design of Infilled Frames". Journal of Structural Engineering, 121(4), pp. 634-650. 1995. https://doi.org/10.1061/(ASCE)0733-9445(1995)121:4(634)

[12] Shing, P. B., Mehrabi, A. B. "Behaviour and Analysis of Masonry-infilled Frames". Progress in Structural Engineering and Materials, 4(3), pp. 320-331. 2002.

https://doi.org/10.1002/pse.122

[13] Smith, S. B., Carter, C. "A method of analysis for infilled frames". Proceedings of the Institution of Civil Engineering, 44(1), pp. 31-48. 1969. https://doi.org/10.1680/iicep.1969.7290

[14] Tasnimi, A. A., Mohebkhah, A. "Investigation on the behaviour of brick infilled steel frames with openings, experimental and analytical approaches". Engineering Structures, 33(3), pp. 968-980. 2011. https://doi.org/10.1016/j.engstruct.2010.12.018 